\title{
The patterns of soil microbial respiration and earthworm communities as influenced by soil and land-use type in selected soils of Hungary
}

\author{
Tsedekech Gebremeskel Weldmichael, Tamás Szegi*, Lubangakene Denish, Ravi Kumar Gangwar, \\ Erika Michéli, Barbara Simon \\ Szent István University, Faculty of Agriculture and Environmental Science, Department of Soil Science, Páter Károly u. 1, 2100, Gödöllő, Hungary \\ * Tamás Szegi, PhD, Szegi.Tamas@mkk.szie.hu, ORCID iD: https://orcid.org/0000-0002-9280-617X (T. Szegi)
}

Received: August 21, 2019

Accepted: April 16, 2020

Associated editor: A. Józefowska

\section{Keywords}

Soil biodiversity

Soil microbial respiration

Earthworm community

Land-use

Soil property

\begin{abstract}
The objective of this study was to determine patterns of soil microbial respiration (SMR) and earthworm communities in selected mollic (Chernozems and Phaeozems) and non-mollic (Luvisols and Arenosols) soils of Hungary, across three land-use types (grassland, arable land, and forest). Soil samples, to a depth of $25 \mathrm{~cm}$, were collected from the surrounding areas of seven soil profiles. SMR measured by basal respiration method, was significantly higher in mollic soils compared to nonmollic soils, with highest values in Chernozem soils and lowest in Arenosols. The mean basal respiration did not show significant difference between land-use types within mollic diagnostic category $(p>0.05)$, but it differed within non-mollic category $(p<0.05)$. We found available $\mathrm{Ca}^{2+}(\mathrm{r}=0.80)$, soil moisture content (MC) $(r=0.72)$, and $\mathrm{Mg}^{2+}(\mathrm{r}=0.69)$ to be strongly correlated with SMR. SMR was significantly higher in fine textured soils compared to coarser textured soils. The earthworm biomass and abundance varied significantly across soil and land-use types, however, explicit correlations with any of soil property measured was not observed. A total of five earthworm species were identified, i.e. Aporrectodea caliginosa, Octolasion lacteum, Aporrectodea rosea, Proctodrilus opisthoductus, and Aporrectodea georgii. Earthworm abundance, biomass, and species richness tend to be highest in grassland and lowest in arable land. Generally, in our study, available $\mathrm{Ca}^{2+}$, $\mathrm{Mg}^{2+}$, MC, and texture were the key drivers of the variation in SMR, whereas the earthworm communities were probably more influenced by agricultural activities related to tillage.
\end{abstract}

\section{Introduction}

Following the 1992 Earth Summit in Rio de Janeiro, soil biodiversity has been recognized globally as a crucial player in guaranteeing the functioning of soil and a provider of several ecosystem services essential for human well-being (Orgiazzi et al., 2016). The microbial fraction of the soil is an indispensable component of soil fertility as soil microbes play key roles in soil aggregate formation, nutrient cycling, humification, and degradation of pollutants (Creamer et al., 2016a). Soil fauna, such as earthworms have huge impacts on soil organic matter (SOM) dynamics, nutrient cycling, and infiltration and distribution of water in the soil (Turbé et al., 2010).

In recent years, several studies have shown that the diversity and functioning of soil biota are greatly influenced by soil properties, land-use types, and management practices (a few examples include; Ponge et al., 2013; Tsiafouli et al., 2015; van Leeuwen et al., 2017; Tian et al., 2017; Semenov et al., 2018). Most of the researches, however, have focused on one aspect of soil biodiversity (e.g. species richness, abundance, community structure).
Given the complex nature of interactions among soil organisms and with their abiotic environment, both biological diversity and biological functions need to be considered when assessing and monitoring soil biodiversity (Creamer et al., 2016b). A decade ago, European based program 'EcoFINDER' (Ecological Function and Biodiversity Indicators in European Soils), has identified bioindicators to assess and monitor soil biodiversity across Europe. Among the proposed biodiversity and ecological indicators, earthworms (abundance, biomass, and diversity) and soil microbial respiration (SMR) have been included (Stone et al., 2016). Nevertheless, these indicators have rarely been studied together across a range of soil and land-use types (Creamer et al., 2016b).

SMR is a biological process that converts soil organic matter into atmospheric $\mathrm{CO}_{2}$, in which soil microflora plays a major role (Creamer et al., 2016a). It is an important indicator of soil health as it reflects the level of microbial activity, which is a key factor in mineralization and organic matter decomposition. SMR also relates to soil microbial properties such as microbial biomass and microbial composition (Józefowska et al., 2017). Hence, this indicator will give a measure of soil biological 
functioning (Jones et al., 2008). However, high SMR is not always better because it may indicate loss of soil organic matter due to excessive tillage or other soil degradation process (Chen et al., 2015). Primary factors affecting soil respiration are $\mathrm{pH}$, organic carbon content, total nitrogen, cation exchange capacity (Rutgers et al., 2006), tree species, and soil texture (Józefowska et al., 2017). Further, base cations $\left(\mathrm{Ca}^{2+}, \mathrm{Mg}^{2+}\right.$, and $\left.\mathrm{K}^{+}\right)$have important positive effect on soil microbial activity as cations are required for microbial growth and protein synthesis (Richter et al., 2018).

The use of earthworm as bioindicator relies on their function in promoting processes that are linked to soil health and their potential effect on the management of soil carbon (Lubbers et al., 2017). They contribute to soil fertility through the comminution of organic debris, enhance microbial activity, and contribute to the increase of nutrient availability in soil and mineral absorption by plants (Dewi and Senge, 2015). Number and diversity of earthworms in a soil are considered an important indicator for soil fertility, because these parameters will provide information about various soil characteristics (soil texture, content of organic matter, porosity, acidity, and moisture) (Ivask et al., 2006). Rutgers et al. (2016) described that land-use, vegetation, soil texture, organic matter and soil $\mathrm{pH}$ which are known to strongly affect earthworm communities in Europe.

In this study, we i) described, characterized (FAO, 2006 guidelines), and classified (IUSS Working Group WRB, 2015) selected soils of Hungary, ii) categorized the classified soils into mollic and non-mollic soil groups based on the presence/absence of mollic diagnostic horizon, iii) made a comparison of SMR and earthworm (abundance, biomass, and species richness) patterns between these soil groups and land-use types within each soil diagnostic category. The objective was to determine the variation of SMR and earthworm communities in relation to (i) soil types; comparing mollic and non-mollic soils, (ii) difference in land-use types, with determination the main factors affecting the variability of studied biotic parameters. Mollic soils have deep humus rich fertile surface layer with high content of basic cations, good water holding capacity, and easily available nutrients, which all have positive effects on soil organisms. Hence, we hypothesized that the SMR and earthworm (abundance, biomass, and species richness) would significantly be higher in mollic soils than nonmollic soils. Likewise, due to the negative effects of agricultural activities, such as organic matter depletion and soil disturbance, we expected lower SMR and earthworm populations in arable soils compared to grassland and forest soils.

\section{Materials and methods}

\subsection{Study area}

The study was carried out on the experimental farm of Szent István University at Józsefmajor (JM) nearby Hatvan ( $\mathrm{N} 47^{\circ} 40^{\prime}$ 5", E 19 40' 11"); Gödöllő University forest (GUF), Gödöllő Botanical Garden (GBG), and Szárítópuszta (SZP) in Gödöllő town (N 47 35' 47.65”, E $19^{\circ} 21^{\prime}$ 18.54”). The experimental farm of Józsefmajor is part of North Plain Alluvial Fan which is a small geographical area of the North Hungarian Hills. Luvisols and Chernozems are the dominant soil types in the area. The eleva- tion of the region varies between 128 and $350 \mathrm{~m}$ a.s.l. The mean annual precipitation ranges from $580-610 \mathrm{~mm}$ and the mean annual temperature is $9.5-10^{\circ} \mathrm{C}$. The Gödöllő sites belong to the Gödöllő-Monori hilly region, which is part of Northern Hungarian Mountain Range. The most common soil types in the region are Luvisols, Cambisols, Arenosols, and Chernozems. The mean annual temperature ranges from $9.5-10^{\circ} \mathrm{C}$ and the annual precipitation is about $600 \mathrm{~mm}$. The dominant land-use in the north is forest (45\%), followed by farmland (40\%), and pasture $(8 \%)$. Oak forest (Quercus cerris and Quercus robur) is the dominant natural vegetation, whereas the main crop types in the farmlands are rye, wheat, barley, corn, and sunflower (Dövényi et al., 2008). According to USDA Soil Taxonomy (USDA, 1993), the soil moisture regime at the study sites is ustic and the soil temperature regime is mesic. The arable sites were ploughed land sown with maize plant.

Seven soil profiles, i.e. three at JM, one at each Gödöllő forest sites (GBG, GUF), and two at SZP, were described and characterized according to FAO (2006) guidelines and classified based on IUSS Working Group WRB (2015). The soils at Józsefmajor were classified as Chernozems (CH), those of Gödöllő forest sites were Luvisols (LU), and the Szárítópuszta soils were Phaeozem (PH) and Arenosol (AR). The details of the sites descriptions and the soil names can be found in Table 1.

\subsection{Soil sampling}

In October 2017, soil samples were taken from the surface horizon of 0 to $25 \mathrm{~cm}$, three meters away from the main soil profiles, in three directions. A total of twenty-one bulk soils were taken for physicochemical and SMR analyses, and sixty-three undisturbed soil cores were taken using volumetric cores for bulk density (BD) analysis. Samples for physicochemical analyses were air dried and passed through $2 \mathrm{~mm}$ sieve, whereas samples for SMR were kept at $4^{\circ} \mathrm{C}$ in the refrigerator until the time of analyses.

\subsection{Soil physicochemical analyses}

All laboratory analyses of the physicochemical parameters were performed in triplicates for each soil samples (i.e. nine replicates per soil profile). Soil pH was measured on soil suspended in a solution of deionized water and $1 \mathrm{M} \mathrm{KCl}$ in $1: 2.5$ ratio (w/v) (Buzás, 1988). Bulk density (BD) and soil moisture content (MC) were determined by gravimetric method (Buzás, 1993). Available nitrogen $\left(\mathrm{NH}_{4}-\mathrm{N}\right.$ and $\left.\mathrm{NO}_{3}-\mathrm{N}\right)$ was measured using Parnas-Wagner Apparatus (Egner et al., 1960). Available potassium $\left(\mathrm{K}_{2} \mathrm{O}\right)$ and phosphorus $\left(\mathrm{P}_{2} \mathrm{O}_{5}\right)$ were estimated based on ammonium-lactate solution method (AL method) using flame photometer and UV-VIS spectrophotometer, respectively (Egner et al., 1960). The Walkley-Black technique was used to measure soil organic matter (SOM) (Walkely and Black, 1934). $\mathrm{CaCO}_{3}$ content was determined using Scheibler calcimeter (Buzás 1988). Available $\mathrm{Ca}^{2+}, \mathrm{Mg}^{2+}$, and $\mathrm{Na}^{+}$were extracted $1 \mathrm{~N} \mathrm{KCl}$ and determined by EDTA titration. $\mathrm{Ca}^{2+}$ and $\mathrm{Mg}^{2+}$ were measured by flame atomic absorption spectrophotometry (AAS), whereas $\mathrm{Na}^{+}$was measured by flame emission spectrophotometer (FES) (Egner et al., 1960). $E_{4} / E_{6}$ (ratio of the absorbances at $465 \mathrm{~nm}$ and $665 \mathrm{~nm}$ ) was determined using spectrometer (Page et al., 1982). 
Table 1

Description of the study sites

\begin{tabular}{|c|c|c|c|c|c|c|c|}
\hline Site & $\begin{array}{l}\text { Land-use } \\
\text { type }\end{array}$ & $\begin{array}{l}\text { Soil type (IUSS Working Group WRB, } \\
\text { 2015) }\end{array}$ & Elevation & Topography & Slope & Soil texture & $\begin{array}{l}\text { Parental } \\
\text { material }\end{array}$ \\
\hline JM1 & Arable & $\begin{array}{l}\text { Vermic Calcic Chernozem (Aric, Loamic, } \\
\text { Pachic, Raptic) }\end{array}$ & $149 \mathrm{~m}$ & Very gentle sloping & $1 \%$ & Clay loam & Loess \\
\hline JM2 & Arable & Calcic Chernozem (Aric, Loamic, Raptic) & $139 \mathrm{~m}$ & Gently sloping & $3 \%$ & Clay loam & Loess \\
\hline JM3 & Grassland & $\begin{array}{l}\text { Vermic Gleyic Calcic Chernozem } \\
\text { (Amphiloamic, Bathyclayic, Pachic, } \\
\text { Raptic) }\end{array}$ & $126 \mathrm{~m}$ & Very gentle sloping & $1 \%$ & Silty Clay Loam & $\begin{array}{l}\text { Local alluvial } \\
\text { and colluvial } \\
\text { sediments }\end{array}$ \\
\hline GBG & Forest & $\begin{array}{l}\text { Haplic Luvisol (Amphiloamic, } \\
\text { Bathyclayic, cutanic, Humic, Protovertic) }\end{array}$ & $248 \mathrm{~m}$ & Very gentle sloping & $1 \%$ & Sandy loam & $\begin{array}{l}\text { Sand mixed } \\
\text { with loess }\end{array}$ \\
\hline GUF & Forest & $\begin{array}{l}\text { Calcic Luvisol (Amphiloamic, } \\
\text { Endoarenic, Cutanic, Humic, Raptic) }\end{array}$ & $245 \mathrm{~m}$ & Very gentle sloping & $1 \%$ & Sandy loam & $\begin{array}{l}\text { Sand mixed } \\
\text { with loess }\end{array}$ \\
\hline SZP1 & Grassland & $\begin{array}{l}\text { Calcic Chernic Phaeozem (Loamic, } \\
\text { Pachic) }\end{array}$ & $222 \mathrm{~m}$ & Very gentle sloping & $1 \%$ & Sandy loam & $\begin{array}{l}\text { Loess and } \\
\text { sand }\end{array}$ \\
\hline SZP2 & Arable & $\begin{array}{l}\text { Eutrict Arenosol (Aeolic, Aric, Ochric, } \\
\text { Raptic) }\end{array}$ & $232 \mathrm{~m}$ & Very gentle sloping & $1 \%$ & Sand & $\begin{array}{l}\text { Loess and } \\
\text { sand }\end{array}$ \\
\hline
\end{tabular}

Abbreviations: Józsefmajor 1 (JM1), Józsefmajor 2 (JM2), Józsefmajor 3 (JM3), Gödöllő Botanical Garden (GBG), Gödöllő University Forest (GUF), Szárítópuszta 1 (SZP1) Szárítópuszta 2 (SZP2).

\subsection{Determination of SMR}

The analysis of SMR followed ISO 16072:2002 (E) guideline and Cheng et al. (2013). In short, fifty grams of moist field soil was measured and placed in an airtight jar with a suspended conical flask containing $10 \mathrm{ml}$ of $1.0 \mathrm{M} \mathrm{NaOH}$. The jars were flushed with clean air with low $\mathrm{CO}_{2}$ content, tightly closed and incubated at $22^{\circ} \mathrm{C}$ for ten days. After ten days, the conical flask was removed and $1 \mathrm{ml} \mathrm{BaCl}_{2}$ was added in the $\mathrm{NaOH}$ solution to precipitate the trapped $\mathrm{CO}_{2}$. Three drops of phenolphthalein were added and titrated against $0.5 \mathrm{M} \mathrm{HCl}$. The determination was carried out in triplicates. Controls (triplicate flasks without soil) were also prepared.

\subsection{Earthworm sampling, extraction, and identification}

The extraction of earthworms was done by employing hand sorting method as described by ISO 23611-1:2006 (E) guideline. From each sample point, three soil blocks of $25 \mathrm{~cm} \times 25 \mathrm{~cm}$ x $25 \mathrm{~cm}$ were studied to estimate the total abundance of earthworms (individuals per $\mathrm{m}^{-2}$ (ind. $\left.\mathrm{m}^{-2}\right)$ ), total fresh biomass $\left(\mathrm{g} \mathrm{m}^{-2}\right.$ ), and species richness. Species identification was done using external characteristics as described by Csuzdi and Zicsi (2003).

\subsection{Statistical analyses}

Independent samples t-test was used to detect the variation of the means in SMR and earthworm (abundance, biomass, and species richness) between mollic and non-mollic soil groups and land-use types within diagnostic category $(p=0.05)$. To identify the variation of the means among sites within diagnostic category, two separate ANOVA with Tukey's HSD post hoc tests were performed $(p=0.05)$. Pearson correlation analysis was employed to examine the relationship between biological properties and physicochemical parameters (correlation was assumed significant when $\mathrm{p}<0.05$ ). Principal Component Analysis (PCA) was used to determine powerful parameters affecting the variability of SMR and earthworm communities. All statistical analyses were performed by R statistical software vs. 3.4.3.

\section{Results}

\subsection{Soil physicochemical properties}

SOM ranged from $1.84 \%$ to $3.90 \%$ and from $0.98 \%$ to $3.71 \%$, and BD from $1.27 \mathrm{~g} \mathrm{~cm}^{-3}$ to $1.57 \mathrm{~g} \mathrm{~cm}^{-3}$ and from $1.11 \mathrm{~g} \mathrm{~cm}^{-3}$ to $1.51 \mathrm{~g} \mathrm{~cm}^{-3}$ in mollic and non-mollic soils, respectively. The $\mathrm{pH}-\mathrm{H}_{2} \mathrm{O}$ values ranged from 4.07 in GBG to 8.47 in SZP2. Both MC and the amount of $\mathrm{Mg}^{2+}$ were highest in JM3 (28.58\%, $39.67 \mathrm{mg}$ $\mathrm{kg}^{-1}$ ) and lowest in SZP2 $\left(9.43 \%, 12.17 \mathrm{mg} \mathrm{kg}^{-1}\right)$. The mean $\mathrm{Ca}^{2+}$ content varied from $687.67 \mathrm{mg} \mathrm{kg}^{-1}$ to $1588.00 \mathrm{mg} \mathrm{kg}^{-1}$ and from $268.33 \mathrm{mg} \mathrm{kg}^{-1}$ to $701.00 \mathrm{mg} \mathrm{kg}^{-1}$, that of $\mathrm{Na}^{+}$from $6.78 \mathrm{mg} \mathrm{kg}^{-1}$ to $13.80 \mathrm{mg} \mathrm{kg}^{-1}$ and from $4.59 \mathrm{mg} \mathrm{kg}^{-1}$ to $6.55 \mathrm{mg} \mathrm{kg}^{-1}$ in mollic and non-mollic soils, respectively. $\mathrm{CaCO}_{3}$ was only present at JM3, SZP1, and SZP2 sites, and significantly higher in SZP2. $\mathrm{P}_{2} \mathrm{O}_{5}$ was highest in JM3 and lowest in GUF. While $\mathrm{K}_{2} \mathrm{O}$ was highest in JM3 and lowest in SZP2, $\mathrm{NO}_{3}-\mathrm{N}$ was highest in GBG and lowest in JM3. $\mathrm{E}_{4} / \mathrm{E}_{6}$ was highest in all non-mollic soils compared to mollic soils. $\mathrm{NH}_{4}-\mathrm{N}$ ranged from $1.04 \mathrm{mg} \mathrm{kg}^{-1}$ to $5.09 \mathrm{mg} \mathrm{kg}^{-1}$ and from $3.31 \mathrm{mg} \mathrm{kg}^{-1}$ to $6.59 \mathrm{mg} \mathrm{kg}^{-1}$ in mollic and non-mollic soils, respectively (Table 2 ).

The result of PCA showed that $36 \%$ and $25 \%$ of the total variance across sites were explained by PC1 and PC2, respectively. PC1 clearly separated Chernozem soils from other soils mainly based on $\mathrm{Ca}^{2+}$ whereas soils of GBG, GUF, and SZP1 were differentiated from others and are related to lower $\mathrm{P}_{2} \mathrm{O}_{5}$ concentration (Figure 1). 
Table 2

Soil physicochemical parameters in relation to site and diagnostic category

\begin{tabular}{|c|c|c|c|c|c|c|c|c|}
\hline \multirow{2}{*}{ Parameter } & \multicolumn{4}{|c|}{ Mollic soil sites } & \multicolumn{3}{|c|}{ Non-mollic soil sites } & \multirow{2}{*}{ Sig. 2-tailed } \\
\hline & JM1 & JM2 & JM3 & SZP1 & GBG & GUF & SZP2 & \\
\hline $\begin{array}{l}\mathrm{BD} \\
\left(\mathrm{g} \mathrm{cm}^{-3}\right)\end{array}$ & $\begin{array}{l}1.57 \mathrm{~b} \pm \\
0.04\end{array}$ & $\begin{array}{l}1.56 \mathrm{~b} \pm \\
0.02\end{array}$ & $\begin{array}{l}1.27 \mathrm{a} \pm \\
0.03\end{array}$ & $\begin{array}{l}1.45 \mathrm{~b} \pm \\
0.11\end{array}$ & $\begin{array}{l}1.30 \mathrm{~b} \pm \\
0.03\end{array}$ & $\begin{array}{l}1.11 \mathrm{a} \pm \\
0.04\end{array}$ & $\begin{array}{l}1.51 \mathrm{c} \pm \\
0.04\end{array}$ & $0.048^{*}$ \\
\hline $\begin{array}{l}\text { MC } \\
(\%)\end{array}$ & $\begin{array}{l}16.51 \mathrm{a} \pm \\
0.17\end{array}$ & $\begin{array}{l}18.31 \mathrm{a} \pm \\
1.57\end{array}$ & $\begin{array}{l}28.58 \mathrm{~b} \pm \\
0.76\end{array}$ & $\begin{array}{l}16.57 \mathrm{a} \pm \\
2.78\end{array}$ & $\begin{array}{l}15.05 \mathrm{~b} \pm \\
2.38\end{array}$ & $\begin{array}{l}16.36 \mathrm{~b} \pm \\
1.85\end{array}$ & $\begin{array}{l}9.43 \mathrm{a} \pm \\
1.47\end{array}$ & $0.004^{* *}$ \\
\hline $\begin{array}{l}\text { SOM } \\
(\%)\end{array}$ & $\begin{array}{l}2.44 \mathrm{a} \pm \\
0.29\end{array}$ & $\begin{array}{l}3.39 \mathrm{~b} \pm \\
0.29\end{array}$ & $\begin{array}{l}3.90 \mathrm{~b} \pm \\
0.18\end{array}$ & $\begin{array}{l}1.84 \mathrm{a} \pm \\
0.46\end{array}$ & $\begin{array}{l}3.66 \mathrm{~b} \pm \\
0.56\end{array}$ & $\begin{array}{l}3.71 b \pm \\
0.53\end{array}$ & $\begin{array}{l}0.98 \mathrm{a} \pm \\
0.10\end{array}$ & 0.842 \\
\hline $\mathrm{pH}-\mathrm{H}_{2} \mathrm{O}$ & $\begin{array}{l}7.80 \mathrm{a} \pm \\
0.19\end{array}$ & $\begin{array}{l}7.41 \mathrm{a} \pm \\
0.24\end{array}$ & $\begin{array}{l}7.78 \mathrm{a} \pm \\
0.12\end{array}$ & $\begin{array}{l}7.51 \mathrm{a} \pm \\
0.24\end{array}$ & $\begin{array}{l}4.07 \mathrm{a} \pm \\
0.13\end{array}$ & $\begin{array}{l}5.49 \mathrm{~b} \pm \\
0.68\end{array}$ & $\begin{array}{l}8.47 \mathrm{c} \pm \\
0.04\end{array}$ & $0.039 *$ \\
\hline $\mathrm{pH}-\mathrm{KCl}$ & $\begin{array}{l}7.14 \mathrm{a} \pm \\
0.12\end{array}$ & $\begin{array}{l}6.76 \mathrm{a} \pm \\
0.25\end{array}$ & $\begin{array}{l}7.14 a \pm \\
0.25\end{array}$ & $\begin{array}{l}6.90 \mathrm{a} \pm \\
0.22\end{array}$ & $\begin{array}{l}3.17 \mathrm{a} \pm \\
0.15\end{array}$ & $\begin{array}{l}4.55 b \pm \\
0.76\end{array}$ & $\begin{array}{l}7.89 \mathrm{c} \pm \\
0.14\end{array}$ & $0.037^{*}$ \\
\hline $\begin{array}{l}\mathrm{Ca}^{2+} \\
\left(\mathrm{mg} \mathrm{kg}^{-1}\right)\end{array}$ & $\begin{array}{l}1588.00 \mathrm{~b} \pm \\
58.62\end{array}$ & $\begin{array}{l}901.66 \mathrm{a} \pm \\
44.55\end{array}$ & $\begin{array}{l}1539.33 b \pm \\
82.44\end{array}$ & $\begin{array}{l}687.67 a \pm \\
296.02\end{array}$ & $\begin{array}{l}701.00 \mathrm{~b} \pm \\
208.01\end{array}$ & $\begin{array}{l}268.33 a \pm \\
164.83\end{array}$ & $\begin{array}{l}269.33 a \pm \\
65.16\end{array}$ & $0.000^{* * *}$ \\
\hline $\begin{array}{l}\mathrm{Mg}^{2+} \\
\left(\mathrm{mg} \mathrm{kg}^{-1}\right)\end{array}$ & $\begin{array}{l}38.53 c \pm \\
2.06\end{array}$ & $\begin{array}{l}30.63 b \pm \\
2.22\end{array}$ & $\begin{array}{l}39.67 \mathrm{c} \pm \\
0.81\end{array}$ & $\begin{array}{l}24.90 \mathrm{a} \pm \\
1.77 \\
\end{array}$ & $\begin{array}{l}32.37 \mathrm{~b} \pm \\
6.73\end{array}$ & $\begin{array}{l}20.37 \mathrm{a} \pm \\
3.25\end{array}$ & $\begin{array}{l}12.17 \mathrm{a} \pm \\
2.23\end{array}$ & $0.007^{* *}$ \\
\hline $\begin{array}{l}\mathrm{Na}^{+} \\
\left(\mathrm{mg} \mathrm{kg}^{-1}\right)\end{array}$ & $\begin{array}{l}13.80 \mathrm{c} \pm \\
1.57\end{array}$ & $\begin{array}{l}10.09 \mathrm{ab} \pm \\
1.31\end{array}$ & $\begin{array}{l}6.78 \mathrm{a} \pm \\
0.12\end{array}$ & $\begin{array}{l}11.07 \mathrm{bc} \pm \\
1.67\end{array}$ & $\begin{array}{l}6.55 \mathrm{~b} \pm \\
1.02\end{array}$ & $\begin{array}{l}5.16 \mathrm{a} \pm \\
1.25\end{array}$ & $\begin{array}{l}4.59 \mathrm{a} \pm \\
0.17\end{array}$ & $0.000^{* * *}$ \\
\hline $\begin{array}{l}\mathrm{K}_{2} \mathrm{O} \\
\left(\mathrm{mg} \mathrm{kg}^{-1}\right)\end{array}$ & $\begin{array}{l}235.33 b \pm \\
20.79\end{array}$ & $\begin{array}{l}500.44 \mathrm{c} \pm \\
7.43\end{array}$ & $\begin{array}{l}533.44 c \pm \\
81.21\end{array}$ & $\begin{array}{l}117.88 \mathrm{a} \pm \\
8.00\end{array}$ & $\begin{array}{l}256.22 \mathrm{a} \pm \\
72.94\end{array}$ & $\begin{array}{l}99.17 \mathrm{a} \pm \\
6.09\end{array}$ & $\begin{array}{l}80.66 \mathrm{a} \pm \\
4.21\end{array}$ & $0.004^{* *}$ \\
\hline $\begin{array}{l}\mathrm{CaCO}_{3} \\
(\%)\end{array}$ & $\begin{array}{l}0.00 \mathrm{a} \pm \\
0.00\end{array}$ & $\begin{array}{l}0.00 \mathrm{a} \pm \\
0.00\end{array}$ & $\begin{array}{l}1.52 \mathrm{~b} \pm \\
0.99\end{array}$ & $\begin{array}{l}0.29 \mathrm{ab} \pm \\
0.51\end{array}$ & $\begin{array}{l}0.00 \mathrm{a} \pm \\
0.00\end{array}$ & $\begin{array}{l}0.00 \mathrm{a} \pm \\
0.00\end{array}$ & $\begin{array}{l}10.09 b \pm \\
7.06\end{array}$ & 0.195 \\
\hline $\begin{array}{l}\mathrm{NO}_{3}-\mathrm{N} \\
\left(\mathrm{mg} \mathrm{kg}^{-1}\right)\end{array}$ & $\begin{array}{l}7.01 \mathrm{a} \pm \\
5.89\end{array}$ & $\begin{array}{l}9.51 \mathrm{a} \pm \\
3.60\end{array}$ & $\begin{array}{l}4.87 \mathrm{a} \pm \\
2.71\end{array}$ & $\begin{array}{l}5.70 \mathrm{a} \pm \\
2.96\end{array}$ & $\begin{array}{l}29.73 a \pm \\
15.15\end{array}$ & $\begin{array}{l}14.33 a \pm \\
5.03\end{array}$ & $\begin{array}{l}9.22 \mathrm{a} \pm \\
5.54\end{array}$ & $0.031^{*}$ \\
\hline $\begin{array}{l}\mathrm{NH}_{4}-\mathrm{N} \\
\left(\mathrm{mg} \mathrm{kg}^{-1}\right)\end{array}$ & $\begin{array}{l}1.04 a \pm \\
0.13\end{array}$ & $\begin{array}{l}2.74 a b \pm \\
1.56\end{array}$ & $\begin{array}{l}5.09 \mathrm{~b} \pm \\
2.19\end{array}$ & $\begin{array}{l}4.76 \mathrm{~b} \pm \\
0.25\end{array}$ & $\begin{array}{l}6.53 a \pm \\
2.11\end{array}$ & $\begin{array}{l}6.59 \mathrm{a} \pm \\
2.23\end{array}$ & $\begin{array}{l}3.31 \mathrm{a} \pm \\
1.71\end{array}$ & 0.054 \\
\hline $\begin{array}{l}\mathrm{P}_{2} \mathrm{O}_{5} \\
\left(\mathrm{mg} \mathrm{kg}^{-1}\right)\end{array}$ & $\begin{array}{l}140.33 \mathrm{ab} \pm \\
27.49\end{array}$ & $\begin{array}{l}355.22 \mathrm{bc} \quad \pm \\
34.64\end{array}$ & $\begin{array}{l}504.56 \mathrm{c} \pm \\
189.19\end{array}$ & $\begin{array}{l}49.83 a \pm \\
27.49\end{array}$ & $\begin{array}{l}87.90 \mathrm{~b} \pm \\
6.39\end{array}$ & $\begin{array}{l}17.28 \mathrm{a} \pm \\
10.97 \mathrm{a}\end{array}$ & $\begin{array}{l}159.89 a \pm \\
18.99\end{array}$ & $0.014^{*}$ \\
\hline $\mathrm{E}_{4} / \mathrm{E}_{6}$ & $\begin{array}{l}2.83 a \pm \\
1.21\end{array}$ & $\begin{array}{l}4.55 \mathrm{~b} \pm \\
0.19\end{array}$ & $\begin{array}{l}5.06 \mathrm{~b} \pm \\
0.32\end{array}$ & $\begin{array}{l}4.47 \mathrm{ab} \pm \\
0.08\end{array}$ & $\begin{array}{l}5.95 a \pm \\
0.23\end{array}$ & $\begin{array}{l}6.10 \mathrm{a} \pm \\
0.25\end{array}$ & $\begin{array}{l}6.43 a \pm \\
0.84\end{array}$ & $0.000^{* * *}$ \\
\hline
\end{tabular}

Abbreviations: Bulk density (BD), Soil moisture content (MC), Soil organic matter (SOM), Józsefmajor 1 (JM1), Józsefmajor 2 (JM2), Józsefmajor 3 (JM3), Gödöllő Botanical Garden (GBG), Gödöllő University Forest (GUF), Szárítópuszta 1 (SZP1), Szárítópuszta 2 (SZP2). (n=9, mean \pm standard deviation). Two separate ANOVA were performed, and means are compared. Different letters within row indicate significant differences at $p<0.05$ with respect to site within diagnostic category. Sig. 2-tailed values show significant levels among the two diagnostic categories. *, ** ***: Significant at the 0.05, 0.01, and 0.001 levels, respectively

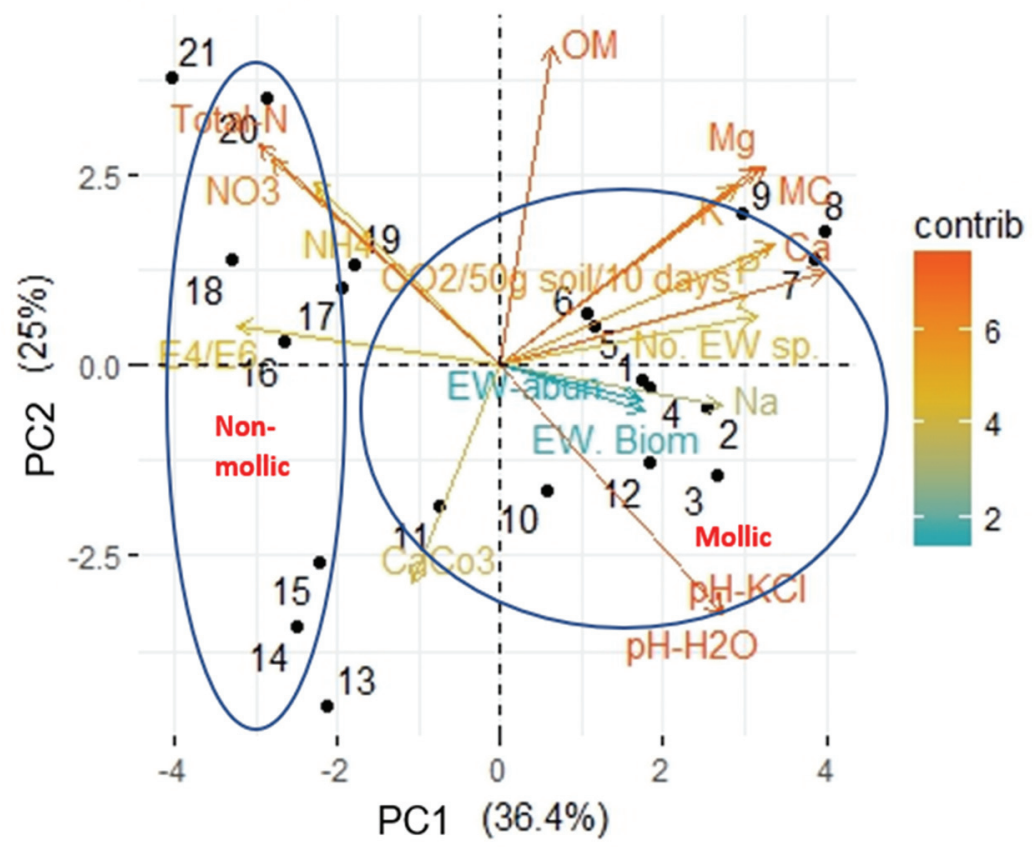

Fig. 1. Principal component analysis showing the variance in soil properties across sites. Sites are coded in number (1-12 mollic soils and 13-21 non-mollic soils). Red colour indicates high level of contribution whereas the blue colour implies low contribution to the total variation 


\subsection{Soil microbial respiration}

SMR was significantly higher in mollic soils compared to non-mollic soils (Table 3). The mean SMR was recorded maximum in JM3 (26.77 $\mathrm{mg} \mathrm{CO}_{2} 50 \mathrm{~g}^{-1}$ soil 10 days $\left.^{-1}\right)$ and minimum in SZP1 (6.78 $\mathrm{mg} \mathrm{CO}_{2} 50 \mathrm{~g}^{-1}$ soil 10 days $^{-1}$ ), higher in GBG and GUF (8.62 mg CO $50 \mathrm{~g}^{-1}$ soil 10 days $^{-1}$ ) and lower in SZP2 (4.40 mg CO $50 \mathrm{~g}^{-1}$ soil 10 days $^{-1}$ ) in mollic and non-mollic soils, respectively (Table 3 ). The mean basal respiration did not show significant difference between land-use types within mollic diagnostic category $(p>0.05)$, but it differed within non-mollic category $(\mathrm{p}<0.05$ ) (Figure 2 ). The SMR significantly varied across soil texture groups $(p<0.001)$, with the greatest amount was recorded in silty clay loam (SiCL) soils and lowest in sandy (S) soils (Figure 3). The result of Pearson's correlation test showed that $\mathrm{Ca}^{2+}(\mathrm{r}=0.80), \mathrm{Mg}^{2+}(\mathrm{r}=0.69)$, and $\mathrm{MC}(\mathrm{r}=0.72)$ were significantly positively correlated with SMR.

Table 3

Soil biological properties in relation to site and diagnostic category

\begin{tabular}{|c|c|c|c|c|c|c|c|c|}
\hline \multirow{2}{*}{ Parameter } & \multicolumn{4}{|c|}{ Mollic soil sites } & \multicolumn{3}{|c|}{ Non- mollic soil sites } & \multirow{2}{*}{ Sig. 2- tailed } \\
\hline & JM1 & JM2 & JM3 & SZP1 & GBG & GUF & SZP2 & \\
\hline $\begin{array}{l}\text { SMR } \\
\left(\mathrm{mg} \mathrm{CO}_{2} 50 \mathrm{~g}^{-1} \text { soil } 10 \text { days }^{-1}\right)\end{array}$ & $\begin{array}{l}19.80 \mathrm{ab} \pm \\
9.19\end{array}$ & $\begin{array}{l}11.73 \mathrm{a} \pm \\
3.90\end{array}$ & $\begin{array}{l}26.77 \mathrm{~b} \pm \\
3.22\end{array}$ & $\begin{array}{l}6.78 \mathrm{a} \pm \\
1.68\end{array}$ & $\begin{array}{l}8.62 \mathrm{a} \pm \\
3.32\end{array}$ & $\begin{array}{l}8.62 \mathrm{a} \pm \\
2.08\end{array}$ & $\begin{array}{l}4.40 \mathrm{a} \pm \\
1.65\end{array}$ & $0.006^{* *}$ \\
\hline $\begin{array}{l}\text { EW abundance } \\
\text { (ind. } \mathrm{m}^{-2} \text { ) }\end{array}$ & $\begin{array}{l}16.00 \mathrm{a} \pm \\
27.71\end{array}$ & $\begin{array}{l}90.67 \mathrm{ab} \pm \\
75.61\end{array}$ & $\begin{array}{l}133.33 \mathrm{ab} \pm \\
40.26\end{array}$ & $\begin{array}{l}336.00 \mathrm{~b} \pm \\
216.44\end{array}$ & $\begin{array}{l}10.67 \mathrm{a} \pm \\
18.47\end{array}$ & $\begin{array}{l}42.67 a \pm \\
40.26\end{array}$ & $\begin{array}{l}0.00 \mathrm{a} \pm \\
0.00\end{array}$ & $0.019^{*}$ \\
\hline $\begin{array}{l}\text { EW biomass } \\
\left(\mathrm{g} \mathrm{m}^{-2}\right)\end{array}$ & $\begin{array}{l}7.87 \mathrm{a} \pm \\
13.63\end{array}$ & $\begin{array}{l}10.22 \mathrm{a} \pm \\
9.75\end{array}$ & $\begin{array}{l}44.67 \mathrm{a} \pm \\
15.09\end{array}$ & $\begin{array}{l}111.39 \mathrm{a} \pm \\
83.67\end{array}$ & $\begin{array}{l}1.00 \mathrm{a} \pm \\
1.71\end{array}$ & $\begin{array}{l}6.84 \mathrm{a} \pm \\
7.38\end{array}$ & $\begin{array}{l}0.00 \mathrm{a} \pm \\
0.00\end{array}$ & $0.030^{*}$ \\
\hline Species richness & $\begin{array}{l}0.33 \mathrm{a}+ \\
0.33\end{array}$ & $\begin{array}{l}0.67 a \pm \\
0.33\end{array}$ & $\begin{array}{l}2.00 \mathrm{a} \pm \\
0.57\end{array}$ & $\begin{array}{l}1.00 \mathrm{a} \pm \\
0.57\end{array}$ & $\begin{array}{l}0.00 \mathrm{a} \pm \\
0.00\end{array}$ & $\begin{array}{l}0.33 a \pm \\
0.33\end{array}$ & $\begin{array}{l}0.00 \mathrm{a} \pm \\
0.00\end{array}$ & $0.009 * *$ \\
\hline
\end{tabular}

Abbreviations: Soil microbial respiration (SMR), EW (Earthworm), Ind. (Individual). Józsefmajor 1 (JM1), Józsefmajor 2 (JM2), Józsefmajor 3 (JM3), Gödöllő Botanical Garden (GBG), Gödöllő University Forest (GUF), Szárítópuszta 1 (SZP1), Szárítópuszta 2 (SZP2). (n=3, mean \pm standard deviation). Two separate ANOVA were performed, and means are compared. Different letters within row indicate significant differences at $\mathrm{p}<0.05$ with respect to site within diagnostic category. Sig. 2-tailed values show significant levels among the two diagnostic categories $\left(^{*}, * *, * * *\right.$ at $0.05,0.01$, and 0.001 , respectively).
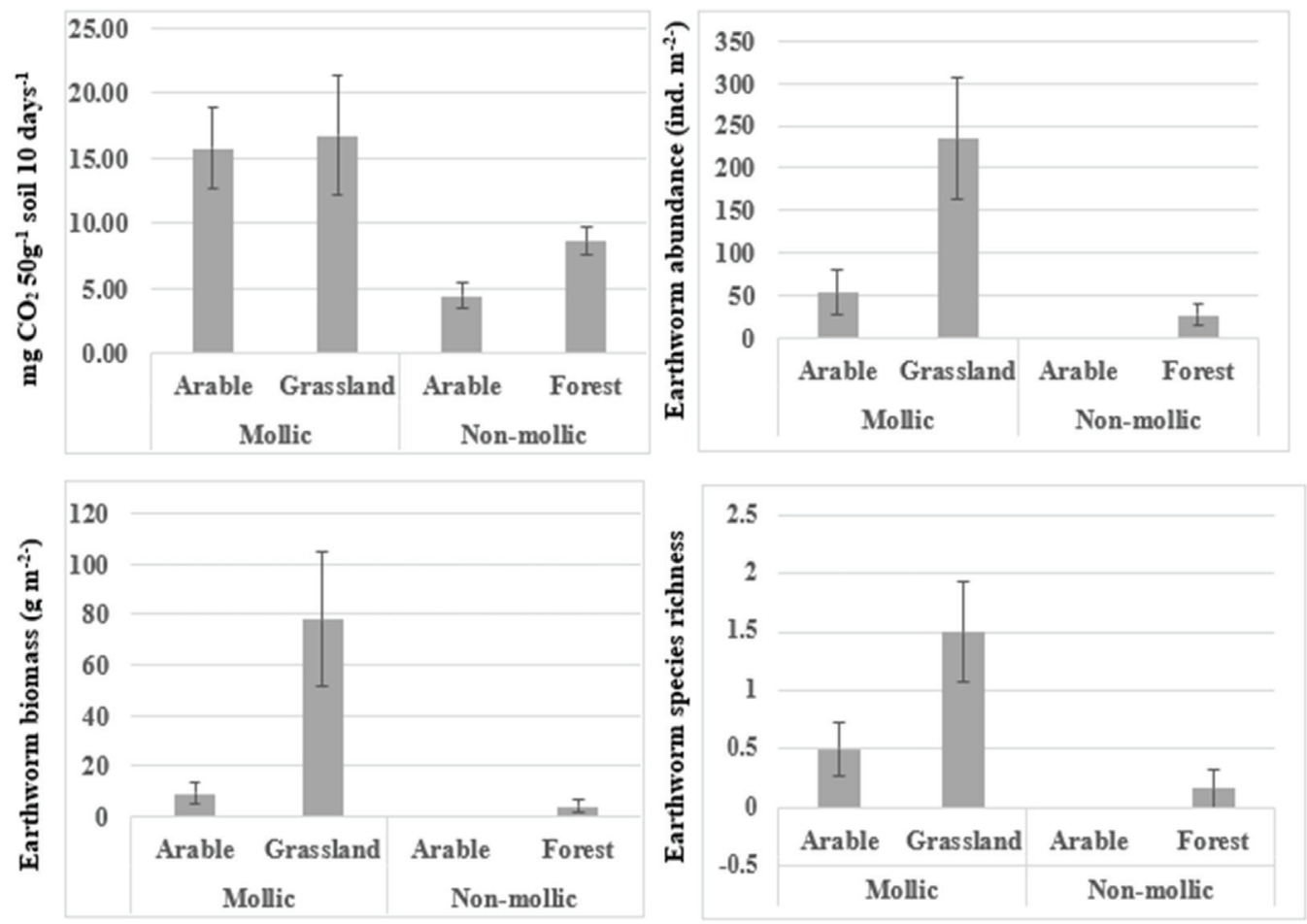

Soil diagnostic category

Fig. 2. Effect of soil and land-use type on SMR and earthworm (abundance, biomass, and species richness) (mean of three measurements and upper and lower error bars showing confidence interval) 


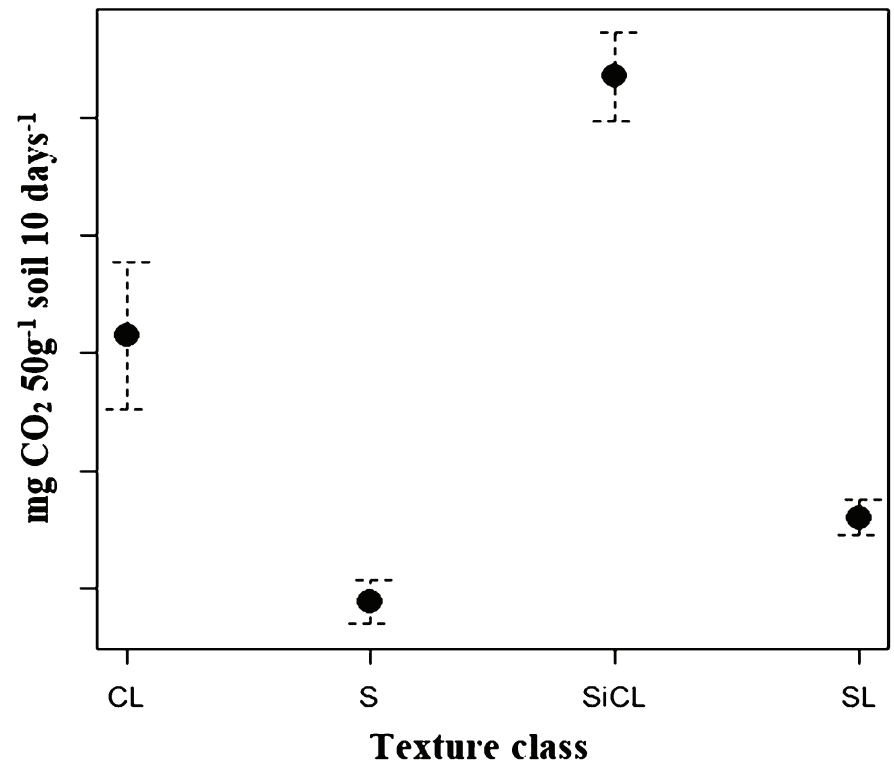

Fig. 3. Mean and standard error of SMR across soil texture classes: CL (Clay Loam), SiCL (Silty Clay Loam), SL (Sandy Loam), and S (Sand)

\subsection{Earthworm abundance, biomass, and species richness}

Earthworm abundance, biomass, and species richness were significantly higher in mollic soils, compared to non-mollic soils (Table 3). Earthworm abundance ranged from 16.00 to 336.00 ind. $\mathrm{m}^{-2}$ and from 0 to 42.67 ind. $\mathrm{m}^{-2}$, earthworm biomass from 7.87 to $111.39 \mathrm{~g} \mathrm{~m}^{-2}$ and from 0 to $6.84 \mathrm{~g} \mathrm{~m}^{-2}$ in mollic and nonmollic soils, respectively (Table 3). Generally, earthworm density and abundance were higher in grassland mollic soils compared to arable mollic soils and forest non-mollic soils compared to arable non-mollic soils (Figure 2). In all sites, the earthworm communities were predominantly dominated by juveniles which represented $90 \%$ in non-mollic and $81 \%$ in mollic soils; $90 \%$ in forest, $88 \%$ in arable, and 64\% in grassland from the total earthworm samples when averaged over soil and land-use types.

A total of five species were identified, i.e. Aporrectodea caliginosa, Octolasion lacteum, Aporrectodea rosea, Proctodrilus opisthoductus, and Aporrectodea georgii. The most common species of earthworm in almost all sites was Aporrectodea caliginosa. The highest species richness was recorded in JM3. This site harboured all species of earthworms identified except Octolasion lacteum, which was only found in SZP1.

\section{Discussion}

\subsection{Variation of SMR in relation to soil and land-use types}

Our results show that SMR significantly varied among the two soil groups, with higher value in mollic soil group $(\mathrm{p}<0.05)$ (Figure 2). Different soil types have distinct physical and chemical properties that lead to different microbial communities and activities. It is well documented that soil properties, such as $\mathrm{pH}$, SOM, and C:N ratio are principal drivers of both SMR and microbial community composition (Moscatelli et al., 2018). In our study, although we found both $\mathrm{pH}$ and SOM were positively correlated with SMR, $\mathrm{Ca}^{2+}(\mathrm{r}=0.80), \mathrm{MC}(\mathrm{r}=0.72)$, and $\mathrm{Mg}^{2+}(\mathrm{r}=0.69)$ were found to be strongly correlated with SMR (Table 4). Based on the result of PCA, the concentration of $\mathrm{Ca}^{2+}$ was the key contributing factor in explaining the total variation in the sites. Accordingly, the SMR significantly separated Chernozems from other soil types, primarily on the bases of higher $\mathrm{Ca}^{2+}$ content (Figure 1). $\mathrm{Ca}^{2+}$ is an important soil macronutrient which may enhance the mineralization of SOM by affecting its labile fractions (Kužel et al., 2010). In Hungary, Filep and Szili-Kovács (2010), with a controlled pot experiment, found that soil respiration was higher in soils limed with $\mathrm{CaCO}_{3}$.

In line with Bååth and Anderson (2003), the present study found a positive correlation between $\mathrm{pH}$ and SMR $(\mathrm{r}=0.23)$, although it was not significant. However, Creamer et al. (2016a), studying the potential microbial activity of European soils across a wide range of physicochemical parameters, contrasting biogeographical (climatic) zones and land-uses, showed a significant negative correlation of $\mathrm{pH}$ with basal respiration. The contradicting result may be due to the difference in the spatial scale considered. We noted a negative correlation between available nitrogen $\left(\mathrm{NO}_{3}-\mathrm{N}\right.$ and $\left.\mathrm{NH}_{4}-\mathrm{N}\right)$ and SMR. Similar observation was made by Gangwar et al. (2018) where $\mathrm{NO}_{3}-\mathrm{N}$ was significantly negatively correlated with SMR in salt affected soils (Solonetz) of Hungary. Kaštovská et al. (2010), suggested $\mathrm{N}$ application may inhibit the biological activity of soil microbes and reduces SMR rates.

This study found a significant variation of SMR among soils of different textures, with the highest value in SiCL soils and lowest in S soils. Soil texture is an important physical property that strongly influences water and nutrient availability in the soil by affecting pore size distribution and surface area. Fine textured soils have a large surface area which allows the soil to hold more nutrients and water that could enhance the microbial activity and in turn increases carbon mineralization (Hamarashid et al., 2010). The SMR was more pronounced in mollic soils than nonmollic soils irrespective of the land-use types, suggesting soil type rather than land-use type might be the driver of basal microbial respiration in the study area. These findings correspond with the work of Katulanda et al. (2018), who concluded that although land-use had influence, the inherent soil properties had a greater influence on soil microbial abundance and therefore on SMR. Similarly, Stępniewska et al. (2020) discussed that SOM and $\mathrm{pH}$ were the most important parameters that influence the abundance and diversity of fungi, a primary decomposer, implying the importance of these variables in SMR.

The correlation analysis showed that there was a strong positive correlation of SMR with $\mathrm{P}_{2} \mathrm{O}_{5}$ and $\mathrm{K}_{2} \mathrm{O}$. Liu et al. (2013) noted that SMR was significantly increased after long-term available $\mathrm{P}$ addition in $\mathrm{N}$-saturated old-growth tropical forest in southern China, suggesting the addition of $\mathrm{P}$ increases labile $\mathrm{C}$ by releasing organic matter bound to the sorption sites. The acidic condition of the forest may result in low $\mathrm{P}_{2} \mathrm{O}_{2}$ availability caused by the binding of large proportion soil $\mathrm{P}_{2} \mathrm{O}_{2}$ to aluminium and iron in forest soils (Mori et al., 2018).

Studies documented that SOM greatly influence the soil microbial activity (Moscatelli et al., 2018), however, this study did not find a strong correlation between these parameters. The 
Table 4

Correlation matrix between physicochemical and biological properties

\begin{tabular}{|c|c|c|c|}
\hline & SMR & Earthworm biomass & Earthworm abundance \\
\hline EW. biomass & -0.013 & & \\
\hline EW. abundance & -0.045 & $0.965^{* * *}$ & \\
\hline $\mathrm{BD}$ & -0.073 & -0.016 & -0.010 \\
\hline $\mathrm{Ca}^{2+}$ & $0.801^{* * *}$ & 0.184 & 0.138 \\
\hline $\mathrm{CaCO}_{3}$ & -0.258 & -0.161 & -0.21 \\
\hline $\mathrm{E}_{4} / \mathrm{E}_{6}$ & $-0.435^{*}$ & -0.215 & -0.217 \\
\hline MC & $0.718^{* *}$ & 0.326 & 0.338 \\
\hline SOM & 0.418 & -0.12 & -0.052 \\
\hline $\mathrm{pH}-\mathrm{H}_{2} \mathrm{O}$ & 0.231 & 0.250 & 0.237 \\
\hline $\mathrm{Mg}^{2+}$ & $0.699 * *$ & 0.087 & 0.073 \\
\hline $\mathrm{Na}^{+}$ & 0.232 & 0.317 & 0.321 \\
\hline $\mathrm{K}_{2} \mathrm{O}$ & $0.647^{* *}$ & -0.056 & 0.000 \\
\hline $\mathrm{NO}_{3}-\mathrm{N}$ & -0.293 & -0.268 & -0.277 \\
\hline $\mathrm{NH}_{4}-\mathrm{N}$ & -0.191 & 0.064 & 0.095 \\
\hline $\mathrm{P}_{2} \mathrm{O}_{5}$ & $0.6277^{*}$ & 0.016 & 0.000 \\
\hline
\end{tabular}

Pearson's correlation $\mathrm{p}<0.05$. $(\mathrm{n}=3)$. *, **, ***: Significant at the $0.05,0.01$, and 0.001 levels, respectively. Abbreviations: Soil organic matter (SOM), Bulk density (BD), Soil moisture content (MC).

reason could be that the positive effect of SOM on SMR might be masked by the negative effect of a low pH on SMR (Creamer et al., 2016a) as the highest SOM was recorded in forest soils where the $\mathrm{pH}$ was lowest. The low $\mathrm{pH}$ in forest soils could negatively affect the microbial activities and consequently decrease the rate of microbial decomposition (Moghimian et al., 2017). Further, the litter quality of forests i.e. high $\mathrm{C}: \mathrm{N}$ and lignin: $\mathrm{N}$ ratio, which is less decomposable, may also play a role for the low microbial respiration in the forest soils (Solly et al., 2014).

\subsection{Pattern of earthworm communities across soil and land-use types}

Both earthworm abundance and biomass greatly differed between mollic and non-mollic soil categories, with the higher mean value recorded in mollic soils. The supply of organic matter in the soil is a key driver of earthworm abundance, as earthworms feed on either poorly decomposed litter at the soil surface or ingest soil and assimilate a small fraction of organic matter it contains (Bertrand et al., 2015). However, this study did not find positive correlation of SOM with earthworm abundance and biomass. Similarly, on the arable soils in France, Pelosi et al. (2009) studied earthworm abundance, biomass, and diversity between conventional and organic farming for three years and found no significant variation between the two management systems despite a high SOM in organic farming system. Studies have shown that the quality of organic matter has an influence on earthworm communities although its effect is species specific (e.g. Solly et al., 2014; Ernst et al., 2009). Generally, earthworms prefer to feed small particle sized over large particle sized organic matter (Lowe and Butt, 2003); organic matter with low C:N ratio over high C:N ratio (Solly et al., 2014). Most of the non-mollic soils in the study area are under forest cover where the $\mathrm{C}: \mathrm{N}$ ratio of the organic matter expected to be high (less humified). Litter with high C:N ratio is less palatable for the earthworms, affecting the earthworms feeding activity, might cause the low earthworm population in non-mollic soils (Ernst et al., 2009). Absence of a significant effect of organic matter on earthworm abundance and biomass in the study area could also be the presence of earthworms in the study area depended on factors more important than organic $\mathrm{C}$, and when present, organic $\mathrm{C}$ is consumed by earthworms. There was a negative correlation between $\mathrm{NO}_{3}-\mathrm{N}$ with both earthworm abundance and biomass. Studies have shown that earthworms can increase the leaching of mineral $\mathrm{N}$ and $\mathrm{P}$ because of their effects on soil structure (Blouin et al., 2013). In this study, earthworm abundance and biomass were generally high in site with high $\mathrm{pH}$.

Earthworm abundance, biomass, and species richness were greater in grassland than arable land in mollic soils and forest compared to arable land in non-mollic soils (Figure 2). The absence of soil tillage coupled with relatively high availability of organic matter in grassland sites may be the reason for the occurrence of high earthworm communities in the grassland sites. A similar observation was made by Varga et al. (2018) and Cluzeau et al. (2012) that the earthworm density, biomass, and species richness were highest in grasslands compared to forest and arable lands. The grassy Chernozem (JM3) soils had the highest number of earthworm species (4 out of 5). Aporrectodea caliginosa was the most abundant earthworm species in the study area. It belongs to the endogeic group and well adapted to pastures, gardens, forest, and even in the poorest 
sandy soils (Csuzdi and Zicsi, 2003). Proctodrilus opisthoductus, Aporrectodea georgii, and Octolasion lacteum were only found in the areas of grassland. The earthworm community majorly constituted the juveniles' category across all soil and land-use type. Similar result was reported by Kamdem et al. (2018). The ratio of juveniles was higher in non-mollic compared to mollic soils, and in forest compared to arable and grassland soils, respectively. Studies documented that the quality of food material affects not only the size of population but also the species present and their rate of growth. Earthworms gain less biomass and mature more slowly when fed with oak leaves (Penning and Wrigley, 2018), this could be the reason why the ratio of juveniles was higher in forest soils compared to other land-use types.

In our study, lacking explicit association of earthworm communities and other soil properties drives us to speculate that agricultural practices related to tillage might have a profound effect on earthworm communities than soil properties. No earthworm was observed in sandy arable soil (SZP2), indicating the combined negative effect of soil texture and agricultural management practices on earthworm communities. Continuous tillage in arable lands may result in high $\mathrm{BD}$, low SOM, and low MC which collectively influence the earthworm communities. Sandy soils are unsuitable for earthworm inhabitation either because the abrasive action of sand grains damages earthworms' cuticle, or because these soils dry out more easily and poor in nutrient and SOM (Hendrix et al., 1992). Crittenden et al. (2014) noted that tillage and farming system explained a significant proportion of total variation in earthworm abundance after studying the effects of tillage systems on earthworm populations in conventional and organic farming in both short-term (15 days) and medium term (3 years) study in the Netherlands. In their review article, Birkás et al. (2010) reported that earthworm live weight in soil under direct till was five times greater than in soil under ridge till and three and half times greater than in soil under conventional tillage in Hungarian soils.

Earthworms enhance SOM decomposition by stimulating SMR and by fragmentizing, ingesting, disintegrating, and transporting fresh plant material into the soil. Earthworms may also affect the SMR by regulating the biomass and/or activity of microbiota and, further, to mineralize/stabilize microbial products (Huang et al., 2015). Conversely, earthworms reduce $\mathrm{CO}_{2}$ flux by promoting aggregation, leading to long tern carbon storage in the soil. The net influence of earthworm on soil carbon dynamics, therefore, depend on the balance of these processes (Lubbers et al., 2017). A recent meta-analysis done by Lubbers et al. (2013) concluded that the presence of earthworms increases soil respiration by an average of $33 \%$. This study, however, did not observe any significant correlation between earthworm (abundance, biomass, and species richness) with SMR. The mechanisms through which earthworms affect SMR is speciesspecific and the overall effects could be positive, negative, and neutral. Studies reported that earthworms induced short-term increases soil respiration, followed by gradual decease back towards the baseline (Chang et al., 2016). Our finding was collaborating with the findings of Chang et al. (2016) and Fisk et al.
(2004) that showed no effect of earthworm on soil respiration. Overall, this study highlighted that land-use type related to tillage could be a more powerful variable than soil properties in explaining earthworm communities in the study area.

\section{Conclusions}

1. The study has demonstrated that the basal respiration was higher in mollic soils compared to non-mollic soils.

2. Available $\mathrm{Ca}^{2+}, \mathrm{MC}$, texture, and $\mathrm{Mg}^{2+}$ were prominent factors affecting SMR.

3. The pattern of earthworm abundance, biomass, and species richness has significantly differed between mollic and nonmollic soils and varied among land-use types within diagnostic category..

4. The influence of plant communities particularly litter quality on soil microbial activity and earthworm communities is difficult to disentangle from the influence of soil characteristics. Hence, further research is needed to investigate vegetation effect on SMR and earthworm communities to obtain a net effect of soil properties and land-use type in the study area. The study may provide a scientific base to design sustainable management strategies that promote the activities and diversity of soil microbes and earthworm communities in the dominant soils of North Hungarian and Gödöllő-Monori hilly regions.

\section{Acknowledgments}

This work was supported by Stipendium Hungaricum Scholarship Program (SHE-935-1/2016), the EFOP-3.6.1-16-20160016 (Evaluations of Human Development Programmes) and by the Higher Education Institutional Excellence Program (N KFIH-1159-6/2019) of the Hungarian Ministry for Innovation and Technology.

\section{References}

Bååth, E., Anderson, T.H., 2003. Comparison of soil fungal/bacterial ratios in a pH gradient using physiological and PLFA-based techniques. Soil Biology and Biochemistry 35(7), 955-963. https://doi.org/10.1016/ S0038-0717(03)00154-8

Bertrand, M., Barot, S., Blouin, M., Whalen, J., de Oliveira, T., Roger-Estrade, J., 2015. Earthworm services for cropping systems. A review. Agronomy for Sustainable Development 35(2), 553-567. https://doi. org/10.1007/s13593-014-0269-7

Birkás, M., Bottlik, L., Stingli, A., Gyuricza, C., Jolánkai, M., 2010. Effect of soil physical state on the earthworms in Hungary. Applied and Environmental Soil Science 2010,1-7. https://doi.org/10.1155/2010/830853

Blouin, M. et al., 2013. A review of earthworm impact on soil function and ecosystem services. European Journal of Soil Science 64(2), 161-182. https://doi.org/10.1111/ejss.12025

Buzás, I. (szerk.), 1988. Talaj- és agrokémiai vizsgálati módszerkönyv 2. A talajok fizikaikémiai és kémiai vizsgálati módszerei. Mezőgazdasági Kiadó, Budapest. p. 90-92, 9698, 106-117, 175-177.

Buzás, I. (szerk.), 1993. Talaj- és agrokémiai vizsgálati módszerkönyv 1. A talaj fizikai, vízgazdálkodási és ásványtani vizsgálata. INDA 4231 Kiadó, Budapest. p. 19, 37-41, 63. 
Chang, C.H., Szlavecz, K., Buyer, J.S., 2016. Species-specific effects of earthworms on microbial communities and the fate of litter-derived carbon. Soil Biology and Biochemistry 100, 1291-39. http://dx.doi. org/10.1016/j.soilbio.2016.06.004

Chen, Z., Dikgwalthe, S.B., Xue, J., Zhang, H., Chen, F., Xiao, X., 2015. Tillage impacts on net carbon flux in paddy soil of the Southern China. Journal of Cleaner Production 103, 70-76. https://doi.org/10.1016/ j.jclepro.2014.05.014

Cheng, F., Peng, X., Zhao, P., Yuan, J., Zhong, C., Cheng, Y., Cui, C., Zhang, S., 2013. Soil microbial biomass, basal respiration and enzyme activity of main forest types in the Qinling Mountains. PLoS One 8(6), 67353. https://doi.org/10.1371/journal.pone.0067353

Cluzeau, D., Guernion M., Chaussod R., Martin-Laurent F., Villenave C., Cortet J., Ruiz-Camacho N., Pernin C., Mateille T., Philippot L., Bellido A., 2012. Integration of biodiversity in soil quality monitoring: baselines for microbial and soil fauna parameters for different landuse types. European Journal of Soil Biology 49, 63-72. https://doi. org/10.1016/j.ejsobi.2011.11.003

Creamer, R.E., Stone, D., Berry, P., Kuiper, I., 2016a. Measuring respiration profiles of soil microbial communities across Europe using MicroRe$\mathrm{sp}^{\mathrm{TM}}$ method. Applied soil ecology 97, 36-43. https://doi.org/10.1016/ j.apsoil.2015.08.004

Creamer, R.E., Hannula, S.E., Van Leeuwen, J.P., Stone, D., Rutgers, M., Schmelz, R.M., De Ruiter, P.C., Hendriksen, N.B., Bolger, T., Bouffaud, M.L., Buee, M., 2016b. Ecological network analysis reveals the interconnection between soil biodiversity and ecosystem function as affected by land use across Europe. Applied Soil Ecology 97, 112-124. https://doi.org/10.1016/j.apsoil.2015.08.006

Crittenden, S.J., Huerta, E., De Goede, R.G.M., Pulleman, M.M., 2015. Earthworm assemblages as affected by field margin strips and tillage intensity: An on-farm approach. European Journal of Soil Biology 66, 49-56. https://doi.org/10.1016/j.ejsobi.2014.11.007

Csuzdi, Cs., Zicsi, A., 2003. Earthworms of Hungary (Annelida: Oligochaeta; Lumbricidae). 271.

Dewi, W.S., Senge, M., 2015. Earthworm diversity and ecosystem services under threat. Reviews in Agricultural Science 3, 25-35. https://doi. org/10.7831/ras.3.0_25

Dövényi, Z., Ambrózy, P., Juhász, Á., Marosi, S., Mezősi, G., Michalkó, G., Tiner, T., 2008. Magyarország Kistájainak Katasztere. OTKA Kutatási Jelentések (Inventory of Microregions in Hungary. OTKA Research Reports).

Egner, J., Riehm, H., Domingo, W., 1960. Untersuchungen über die chemische Bodenanalyse als Grundlage für die Beurteilung des Nährstoffzustandes der Böden II. Chemische Extraktionsmethoden zur Phosphor- und Kaliumbestimmung. Kungliga Lantbrukshögskolans Annaler Ann 26, 199-215.

Ernst, G., Henseler, I., Felten, D., Emmerling, C., 2009. Decomposition and mineralization of energy crop residues governed by earthworms. Soil Biology and Biochemistry 41(7), 1548-1554. https://doi.org/10.1016/ j.soilbio.2009.04.015

FAO, 2006. Guidelines for soil description, Fourth edition. ISBN 92-5105521-1.

Filep, T., Szili-Kovács, T., 2010. Effect of liming on microbial biomass carbon of acidic arenosols in pot experiments. Plant, Soil and Environment 56(6), 268-273.

Fisk, M.C., Fahey, T.J., Groffman, P.M., Bohlen, P.J., 2004. Earthworm invasion, fine-root distributions, and soil respiration in north temperate forests. Ecosystems 7(1), 55-62. https://doi.org/10.1007/s10021-0030130-3

Gangwar, R.K., Makádi, M., Fuchs, M., Csorba, Á., Michéli, E., Demeter, I., Szegi, T., 2018. Comparison of biological and chemical properties of arable and pasture Solonetz soils. Agrokémia és Talajtan 67(1), 61-77. https://doi.org/10.1556/0088.2018.67.1.5

Hamarashid, N.H., Othman, M.A., Hussain, M.A.H., 2010. Effects of soil texture on chemical compositions, microbial populations and carbon mineralization in soil. The Egyptian Society of Experimental Biology 6(1), 59-64.

Hendrix, P.F., Mueller, B.R., Bruce, R.R., Langdale, G.W., Parmelee, R.W., 1992. Abundance and distribution of earthworms in relation to landscape factors on the Georgia Piedmont, USA. Soil Biology and Biochemistry 24(12), 1357-1361. https://doi.org/10.1016/00380717(92)90118-H

Huang, J., Zhang, W., Liu, M., Briones, M.J., Eisenhauer, N., Shao, Y., Cai, X.A., Fu, S., Xia, H., 2015. Different impacts of native and exotic earthworms on rhizodeposit carbon sequestration in a subtropical soil. Soil Biology and Biochemistry 90, 152-160. https://doi.org/10.1016/ j.soilbio.2015.08.011

ISO - INTERNATIONAL STANDARD ISO16072 (First edition 2002.12.15.) Soil quality - Laboratory methods for determination of microbial soil respiration. Reference number: ISO 16072:2002 (E).

ISO - INTERNATIONAL STANDARD ISO23611-1 (First edition 2006.02.01.) Soil quality - Sampling of soil invertebrates - Part 1: Hand-sorting and formalin extraction of earthworms, Reference number: ISO 23611-1:2006 (E).

IUSS Working Group WRB., 2015. World Reference Base for Soil Resources 2014, update 2015 International soil classification system for naming soils and creating legends for soil maps. World Soil Resources Reports No. 106. FAO, Rome.

Ivask, M., Kuu, A., Truu, M., Truu, J., 2006. The effect of soil type and soil moisture on earthworm communities. Agricultural Science 17, 7-11.

Jones, R.J.A., Verheijen, F.G.A., Reuter, H.I., Jones, A.R., 2008. Environmental assessment of soil for monitoring volume V: Procedures \& protocols. EUR23490 EN/5. Office for the Official Publications of the European Communities, Luxembourg, 165 pp. http://doi.org/ 10.2788/94366eusoils. jrc. ec. europa. eu/ESDB_Archive/eusoils_docs/ doc. html (July, 2013).

Józefowska, A., Pietrzykowski, M., Woś, B., Cajthaml, T., Frouz, J., 2017. Relationships between respiration, chemical and microbial properties of afforested mine soils with different soil texture and tree species: Does the time of incubation matter. European journal of soil biology 80, 102-109. https://doi.org/10.1016/j.ejsobi.2017.05.004

Kamdem, M.M., Otomo, P.V., Ngakou, A., Yanou, N.N., 2018. Distribution and diversity of earthworm (Annelida, Clitellata) populations across four land use types in northern Cameroon. Turkish Journal of Zoology 42(1), 79-89. https://doi.org/10.3906/zoo-1704-52

Kaštovská, E., Šantrůčková, H., Picek, T., Vašková, M., Edwards, K.R., 2010. Direct effect of fertilization on microbial carbon transformation in grassland soils in dependence on the substrate quality. Journal of Plant Nutrition and Soil Science 173(5), 706-714. https://doi. org/10.1002/jpln.200900013

Katulanda, P.M., Walley, F.L., Janzen, H.H., Helgason, B.L., 2018. Land use legacy regulates microbial community composition in transplanted Chernozems. Applied Soil Ecology 129, 13-23. https://doi.org/10.1016/ j.apsoil.2018.03.001

Kužel, S., Kolář, L., Gergel, J., Peterka, J., Borova-Batt, J., 2010. Influence of the degree of soil organic matter lability on the calcium carbonate equilibrium of soil water. Soil and Water Research 5(2), 58-68. https:// doi.org/10.17221/18/2009-SWR

Liu, L, Zhang, T., Gilliam, F.S., Gundersen, P., Zhang, W., Chen, H., Mo, J., 2013. Interactive effects of nitrogen and phosphorus on soil microbial communities in a tropical forest. PLoS One 8(4), 61188. https://doi. org/10.1371/journal.pone.0061188

Lowe, C.N., Butt, K.R., 2003. Influence of food particle size on inter- and intra-specific interactions of Allolobophora chlorotica (Savigny) and Lumbricus terrestris. Pedobiologia 47, 574-577.

Lubbers, I.M., Pulleman, M.M., Van Groenigen, J.W., 2017. Can earthworms simultaneously enhance decomposition and stabilization of plant residue carbon? Soil Biology and Biochemistry 105, 12-24. https://doi.org/10.1016/j.soilbio.2016.11.008 
Lubbers, I.M., Van Groenigen, K.J., Fonte, S.J., Six, J., Brussaard, L., Van Groenigen, J.W., 2013. Greenhouse-gas emissions from soils increased by earthworms. Nature Climate Change 3(3), 87-194. https://doi. org/10.1038/NCLIMATE1692

Moghimian, N., Hosseini, S.M., Kooch, Y., Darki, B.Z., 2017. Impacts of changes in land use/cover on soil microbial and enzyme activities. Catena 157, 407-414. https://doi.org/10.1016/j.catena.2017.06.003

Mori, T., Lu, X., Aoyagi, R., Mo, J., 2018. Reconsidering the phosphorus limitation of soil microbial activity in tropical forests. Functional Ecology 32(5), 1145-1154. https://doi.org/10.1111/1365-2435.13043

Moscatelli, M.C., Secondi, L., Marabottini, R., Papp, R., Stazi, S.R., Mania, E., Marinari, S., 2018. Assessment of soil microbial functional diversity: land use and soil properties affect CLPP-MicroResp and enzymes responses. Pedobiologia 66, 36-42. https://doi.org/10.1016/ j.pedobi.2018.01.001

Orgiazzi, A., Panagos, P., Yigini, Y., Dunbar, M.B., Gardi, C., Montanarella, L., Ballabio, C., 2016. A knowledge-based approach to estimating the magnitude and spatial patterns of potential threats to soil biodiversity. Science of the Total Environment 545, 11-20. https://doi. org/10.1016/j.scitotenv.2015.12.092

Page, A.L., Mille, R.H., Keeney, D.R. (ED.), 1982. Methods of soil analysis. Part 2 (2nd edition). Agronomy monograph 9. ASA and SSSA, Madison, WI, 591-592.

Pelosi, C., Bertrand, M., Roger-Estrade, J., 2009. Earthworm community in conventional, organic and direct seeding with living mulch cropping systems. Agronomy for Sustainable Development 29(2), 287-295. https://doi.org/10.1051/agro/2008069

Penning, K.A., Wrigley, D.M., 2018. Aged Eisenia fetida earthworms exhibit decreased reproductive success. Invertebrate reproduction \& development 62(2), 67-73. https://doi.org/10.1080/07924259.2017.140 9287

Ponge, J.F., Pérès G., Guernion M., Ruiz-Camacho N., Cortet J., Pernin C., Villenave C., Chaussod R., Martin-Laurent F., Bispo A., Cluzeau D., 2013. The impact of agricultural practices on soil biota: a regional study. Soil Biology and Biochemistry 67, 271-284.

Richter, A., Huallacháin, D.Ó., Doyle, E., Clipson, N., Van Leeuwen, J.P., Heuvelink, G.B., Creamer, R.E., 2018. Linking diagnostic features to soil microbial biomass and respiration in agricultural grassland soil: a large scale study in Ireland. European Journal of Soil Science 69(3), 414-428. https://doi.org/10.1111/ejss.12551

Rutgers, M., Orgiazzi, A., Gardi, C., Römbke, J., Jänsch, S., Keith, A.M., Neilson, R., Boag, B., Schmidt, O., Murchie, A.K. and Blackshaw, R.P., 2016. Mapping earthworm communities in Europe. Applied Soil Ecology 97, 98-111. https://doi.org/10.1016/j.apsoil.2015.08.015.

Semenov, M.V., Chernov, T.I., Tkhakakhova, A.K., Zhelezova, A.D., Ivanova, E.A., Kolganova, T.V., Kutovaya, O.V., 2018. Distribution of prokaryo- tic communities throughout the Chernozem profiles under different land uses for over a century. Applied Soil Ecology 127, 8-18. https:// doi.org/10.1016/j.apsoil.2018.03.002

Soil Survey Division Staff, 1993. Soil Survey Manual, USDA Handbook, 18: 315.

Solly, E.F., Schöning, I., Boch, S., Kandeler, E., Marhan, S., Michalzik, B., Müller, J., Zscheischler, J., Trumbore, S.E., Schrumpf, M., 2014. Factors controlling decomposition rates of fine root litter in temperate forests and grasslands. Plant and Soil 382(1-2), 203-218. https://doi. org/10.1007/s11104-014-2151-4

Stępniewska, H., Uzarowicz, Ł., Błońska, E., Kwasowski, W., Słodczyk, Z., Gałka, D., Hebda, A., 2020. Fungal abundance and diversity as influenced by properties of Technosols developed from mine wastes containing iron sulphides: A case study from abandoned iron sulphide and uranium mine in Rudki, south-central Poland. Applied Soil Ecology 145. https://doi.org/10.1016/j.apsoil.2019.08.011

Stone, D., Blomkvist, P., Hendriksen, N.B., Bonkowski, M., Jørgensen, H.B., Carvalho, F., Dunbar, M.B., Gardi, C., Geisen, S., Griffiths, R., Hug, A.S., 2016. A method of establishing a transect for biodiversity and ecosystem function monitoring across Europe. Applied Soil Ecology 97, 3-11. https://doi.org/10.1016/j.apsoil.2015.06.017

Tian, Q., Taniguchi, T., Shi, W.Y., Li, G., Yamanaka, N., Du, S., 2017. Landuse types and soil chemical properties influence soil microbial communities in the semiarid Loess Plateau region in China. Scientific reports 7, 45289. https://doi.org/10.1038/srep45289

Tsiafouli, M.A., Thébault E., Sgardelis S.P., De Ruiter P.C., Van Der Putten W.H., Birkhofer K., Hemerik L., De Vries F.T., Bardgett R.D., Brady M.V., Bjornlund L., 2015. Intensive agriculture reduces soil biodiversity across Europe. Global Change Biology 21(2), 973-985. https://doi. org/10.1111/gcb.12752.

Turbé, A., De Toni, A., Benito, P., Lavelle, P., Lavelle, P., Camacho, N.R., Van Der Putten, W.H., Labouze, E., Mudgal, S., 2010. Soil biodiversity: functions, threats and tools for policy makers.

Van Leeuwen, J.P., Djukic, I., Bloem, J., Lehtinen, T., Hemerik, L., de Ruiter, P.C., Lair, G.J., 2017. Effects of land use on soil microbial biomass, activity and community structure at different soil depths in the Danube floodplain. European Journal of Soil Biology 79, 14-20. https://doi. org/10.1016/j.ejsobi.2017.02.001

Varga, J., Kanianska, R., Spišiak, J., 2018. Impact of land use and geological conditions on selected physical soil properties in relation to the earthworm abundance and biomass along an altitudinal gradient in Slovakia. Soil Science Annual 69(3), 160-168. https://doi.org/10.2478/ ssa-2018-0016

Walkley, A., Black, I. A., 1934. An examination of the Degtjareff method for determining soil organic matter, and a proposed modification of the chromic acid titration method. Soil Science 37, 29-38. 